\title{
Hvor er du?
}

\author{
Hvor er du som ser hele pasienten? Hvor er du som vet om pasientens vondter, plager og sårbarhet? \\ Du som vet at hodet henger sammen med kroppen, og motsatt. Hvor er du som ikke bare ser organsystemer, \\ men også et helt menneske der i sengen under dynen?
}

Ser du pasienten som ikke klarer å følge legen mer enn tre ord om gangen? Han er alvorlig syk og ligger der med vidåpne øyne. Han forstår ikke hvorfor han først ble innlagt på én avdeling, så på en annen for så å få tilsyn fra en tredje. Pasienten er redd og skjønner ikke helt hva det vil si å bli «flyttet over på medisin». Er ikke alle avdelinger medisinske, da? Er det ikke et sykehus han er kommet til? Eller er han blitt riv, ruskende gal? Det er vel det siste som mangler at det kommer en psykiater, for her har det allerede vært kirurger, indremedisinere og en ortoped, og alle snakker et språk han ikke forstår.

Jeg er hun studenten. Hun som ser på, smiler og strekker hånden frem for å hilse, men som ikke rekker det. Pasienten lurer sikkert på hvorfor jeg smiler, for dette er jo ikke morsomt i det hele tatt. Dette er tvert imot kaos - og veldig vondt.

\section{Noe er galt, men hva?}

Hvor er du som tar deg en prat med den gamle damen som ikke vil hjem? Hun som har vært utredet hos alle, men som alltid får høre at alt er i sin skjønneste orden. Hun som ikke er bra i kroppen og føler seg uvel. Som har en visshet om at noe er alvorlig galt, men hun vet ikke hva det er. Det hun vet, er at det finnes mange leger og at de har studert menneskekroppen i mangfoldige år. De burde vite hva som er galt og slett ikke fortelle henne at alt er i skjønneste orden. For det er det ikke! Hvor er du da? Du som ser hele dette mennesket og hele denne kroppen som er så uvel?

Jeg er fremdeles studenten. Jeg står halvveis bak gardinen og smiler, et litt høflig og kanskje trist smil. Det er meg igjen, ja, jeg som var på visitten $i$ går og dagen før der igjen. Og når legen ber damen fortelle hva som egentlig har skjedd, ser hun spørrende bort på meg. For jeg vet vel hva som har skjedd? Jeg har jo vært her siden hun ble innlagt, og jeg har hørt henne gjenta historien om hva som egentlig har skjedd opptil flere ganger. Er jeg blitt helt riv, ruskende gal? tenker hun, eller må jeg fortelle alt på nytt hver eneste dag?

\section{Man skal utelukke hjerteinfarkt ved brystsmerter}

Hvor er du egentlig, du som forstår? Du som skjønner at det er utrolig frustrerende å havne på en hjerteavdeling når man egentlig har mest vondt $\mathrm{i}$ hodet. «Hvordan går det med deg i dag?» spør legen. «Jo, det går greit nok, men jeg har veldig vondt $i$ hodet,» sier kvinnen som har tatt leppestift på til visitten. Assistentlegen er travel, men grundig og leter etter mulige tegn på hjerteinfarkt. Ser etter troponinstigning i papirene, sjekker EKG. Spør etter brystsmerter, smerter i armen, vondt i ryggen, koronare risikofaktorer. «Røyker du?» spør legen.

Den søte kvinnen med leppestiften lurer på om legen hørte hva hun sa. Hun lurer på om han tror hun røyker inne på et sykehus! Og hva har røykingen egentlig med hodepinen å gjøre? Hun får mer vondt i hodet, og det skarpe sykehuslyset skjærer i øynene. Hun sier: «Det eneste som plager meg, er denne hodepinen.» «Det er bra,» sier legen og er på vei til å gå. Bra? tenker damen i sengen og ser forundret på meg, studenten som står der som en del av sykehustapetet og smiler anstrengt. Hun i sengen vrir seg og tar seg til pannen.

Hvor er du egentlig da? Du som skjønner at disse spørsmålene virker malplassert for damen med leppestift, men som også skjønner at legen må stille disse spørsmålene. Du forstår godt legen, du vet at han er travel og må holde seg til det som er viktig. Fordi man skal utelukke hjerteinfarkt ved brystsmerter. Det er jobben hans som assistentlege på hjerteavdelingen. Men du vet også at denne damen den siste uken har opplevd sitt livs største katastrofe. Du vet det fordi du har spurt henne. Og det er kanskje ikke annet å vente når man har opplevd noe slikt? Da får man brystsmerter, vondt i ryggen og hodepine. $\mathrm{Og}$ det vet du. Fordi du ser hele henne.

\section{Hva betyr «ingen tegn til iskemi»?}

Hvor er du når den livredde pasienten som opprinnelig ble lagt inn på kirurgisk avdeling trenger intravenøs antibiotikabehandling, men ikke blir forklart hvorfor? Hvor er du når damen som har vondt $i$ kroppen blir skrevet ut? Det ble ikke funnet noe galt mens hun var innlagt, men hun har fremdeles like vondt og like mange plager når hun må ta lokalbussen hjem alene som da hun lå på avdelingen. Legen har ingen medisinske begrunnelser for at hun skal få dekket drosje hjem, men for henne finnes det ingen kloke begrunnelser for å dra hjem i det hele tatt. Hvor er du egentlig da?

Og hva med hun med leppestift? Hun har ikke hjerteinfarkt. Og i pasientskrivet hennes står det akkurat det. Hun har ikke hjerteinfarkt, men hun har fryktelig vondt i hodet. Hun har heldigvis noen som henter henne, for kjøre kan hun jo ikke. Det står «ingen tegn til iskemi». Hva betyr egentlig det? At hun er frisk? Hjerteavdelingen sier hun er frisk. Det utgjør ingen forskjell for damen med leppestift, for hun har vondt i hodet etter å ha opplevd sitt livs største katastrofe.

\section{Hvem er du egentlig?}

Kanskje er du fastlegen? Kanskje er du en god venn, samboeren, psykologen, hjertespesialisten eller sykepleieren på post? Forhåpentligvis er du alle dem og forhåpent-

ligvis er det mange av deg. Kanskje kan jeg bli som deg? Noen vil kalle dette irrasjonelt og idealistisk. Andre sier at tanken er god, men at tiden ikke strekker til. Noen sier jeg vil bli utslitt. «Det er fint å bry seg om hele mennesket,» sa en lege til meg en av dagene i praksisperioden, «men da bør du bli allmennpraktiker, og da blir du definitivt en utbrent allmennpraktiker.»

Der og da trodde jeg han hadde rett, men jeg håper han tar feil. Jeg tror ikke man blir mer sliten av å se hele mennesket. Jeg undrer meg over argumentet om at man blir sliten om man bryr seg så mye. Dersom jeg ikke gjør det, er det ikke nettopp da jeg vil gå hjem med en følelse av utilstrekkelighet hver eneste dag? Og hvis man ikke blir sliten av å føle seg utilstrekkelig, hva blir man sliten av da?

Jeg mener at både vi studenter og ferdig utdannede leger kan trenes i å se hele mennesket. Det er mulig å lære empati, kommunikasjonsferdigheter, respekt, omsorg, medfølelse, integritet, ærlighet, ansvarlighet og altruisme - på lik linje som vi lærer praktiske ferdigheter og faktakunnskap. Og jeg tror det er nødvendig. Det må være rom for å diskutere, reflektere og gruble. Vi studenter kan ikke bare tåle gjennom seks år, uten refleksjon rundt hva vi faktisk opplever. Uten trening i disse temaene - hvordan skal vi da ha redskaper, kunnskap eller ork nok til å se ordentlig etter? På hele det mennesket vi har foran oss. 


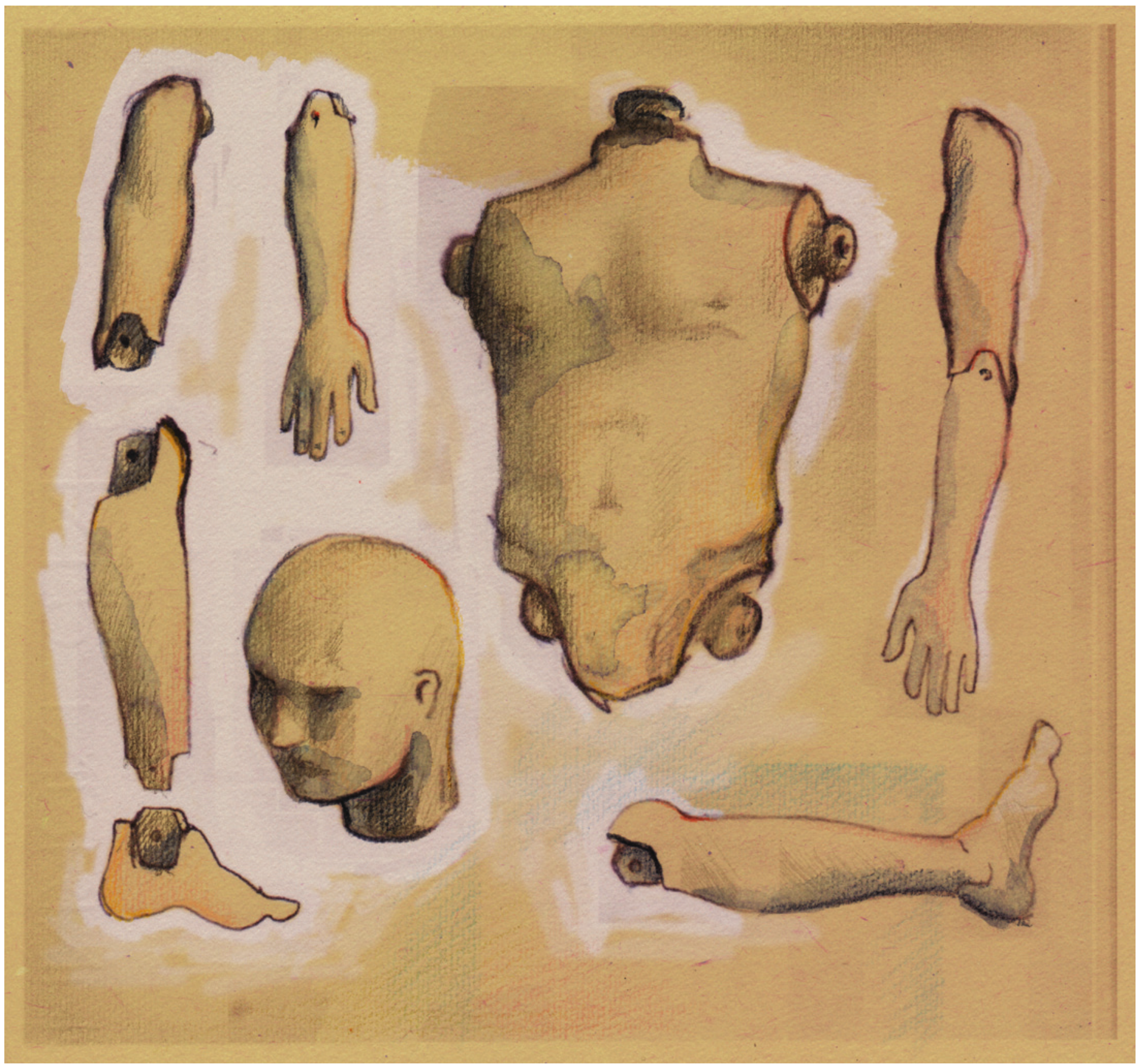

Illustrasjon @ Stein Løken

\section{Hele mennesket}

Så hva er egentlig vårt ansvar? Hvor går grensen mellom et helt menneskets helse og våre faktiske arbeidsoppgaver? Er det mulig å se hele mennesket til tross for at man må konsentrere seg om en liten bit? Etter fem år på dette studiet har jeg kommet til den erkjennelse at jeg som lege faktisk ikke kan kurere alle vondter eller hjelpe alle mennesker med alle deres problemer. Men er det én ting jeg tror vi kan, så er det å være hele mennesker, vi og. Vi kan være medmennesker. Hver dag og hver gang med hvert eneste hele menneske. Er det kanskje det som kalles profesjonalitet?

Pasienthistoriene er konstruert på bakgrunn av en rekke tilfeller, slik at de faktiske pasientene bak ikke er gjenkjennelige.

Jeg takker medstudent Anne Sofie Paus for inspirasjon m.m.

\section{Ingrid Neteland}

ingrid.neteland@student.uib.no
Ingrid Neteland (f. 1987) er medisinstudent ved Universitetet i Bergen og nestleder i Medisinsk fagutvalg i Bergen.

Mottatt 23.4. 2012, første revisjon innsendt 23.5. 2013, godkjent 31.5. 2013. Medisinsk redaktør Merete Kile Holtermann. 